\title{
Case report: \\ THROMBOCYTOPENIA IN A PATIENT UNDERGOING PRIMARY PERCUTANEOUS CORONARY INTERVENTION
}

\author{
Yudi Her Oktaviono, Feranti Meuthia \\ Department of Cardiology \& Vascular Medicine, Faculty of Medicine, Universitas Airlangga, Dr. Soetomo Hospital, \\ Surabaya, Indonesia
}

\section{ABSTRACT}

\begin{abstract}
Thrombocytopenia is a common abnormality in patients presenting with acute coronary syndrome. Baseline thrombocytopenia in patients with ST-elevation myocardial infarction undergoing primary percutaneous coronary intervention is associated with early adverse events, related to both ischemia and bleeding. Treatment for acute coronary syndrome usually involves antiplatelet, anticoagulant, antithrombotic therapy, and the performance of percutaneous coronary intervention. The safety of antiplatelet therapy and percutaneous coronary intervention patients who have acute coronary syndrome and thrombocytopenia is unknown, and there are no guidelines or randomized studies that specifically suggest a treatment approach in such patients. One of the institutions in Italy recommends medical and interventional strategy with radialis as first choice for access site, bare metal stent (BMS) implantation, followed by double antiplatelet therapy (DAPT) for one month. After DAPT discontinuation, at least one antiplatelet drug (aspirin) is recommended for life.
\end{abstract}

Keywords: Thrombocytopenia; percutaneous coronoray intervention; acute coronary syndrome

\section{ABSTRAK}

Trombositopenia adalah kelainan umum pada pasien dengan sindrom koroner akut. Trombosis awal pada pasien dengan peningkatan infark miokard ST yang menjalani intervensi koroner perkutan primer dikaitkan dengan efek samping awal, terkait dengan iskemia dan perdarahan. Perawatan untuk sindrom koroner akut biasanya melibatkan antiplatelet, antikoagulan, terapi antitrombotik, dan kinerja intervensi koroner perkutan. Keamanan terapi antiplatelet dan intervensi koroner perkutan pada pasien yang memiliki sindrom koroner akut dan trombositopenia tidak diketahui, dan tidak ada studi acak yang secara khusus menyarankan pendekatan pengobatan dalam strategi medis dan intervensi dengan radial sebagai pilihan pertama untuk situs akses, stent metal telanjang (Implantasi BMS), diikuti dengan terapi antiplatelet ganda (DAPT) selama satu bulan. Setelah penghentian DAPT, setidaknya satu obat antiplatelet (aspirin) direkomendasikan untuk seumur hidup.

Kata kunci: Trombositopenia; intervensi koroner perkutan; sindrom koroner akut

Correspondence: Yudi Her Oktaviono, Department of Cardiology, Faculty of Medicine, Universitas Airlangga, Dr. Soetomo Hospital, Surabaya. Email: yhoktaviono@yahoo.com

pISSN:2355-8393 • eISSN: 2599-056x • doi: http://dx.doi.org/10.20473/fmi.v55i1.12562

- Fol Med Indones. 2019;55:68-73 • Received 20 Apr 2017 • Accepted 24 Aug 2017

- Open access under CC-BY-NC-SA license • Available at https://e-journal.unair.ac.id/FMI/

\section{INTRODUCTION}

Platelets have an important role in the pathogenesis of acute coronary syndrome (SKA). Thrombocytopenia, an abnormality that is sometimes found in people with SKA, is one of the risk factors for bleeding and other cardiac events in patients with SKA who are treated with antithrombotic (Hakim et al 2011). Standard therapy for acute coronary syndrome includes antiplatelet, anticoagulant, and thrombolytic agents, as well as percutaneous coronary intervention (PCI). All of these therapies are associated with a risk of bleeding and are usually delayed in patients with thrombo- cytopenia. The safety level of antiplatelet and PCI therapy in people with SKA with thrombocytopenia is unknown, and there are no randomized guidelines or studies that suggest a therapeutic approach in these patients (Hakim et al 2011). Here we report the case of a patient with acute coronary syndrome with thrombocytopenia performed by a primary PCI.

\section{CASE REPORT}

Mr. J, 52 years, went to the IRD Cardiac section with complaints of chest pain that penetrated his back 1 hour 
before being hospitalized. Pain was felt when the patient was washing the car. Complaints were accompanied by palpitations and cold sweat. The patient did not complain of nausea and vomiting. Previous medical history showed that he did not have hypertension and stroke, but patient had suffered from diabetes mellitus for 10 years, erosival gastritis and liver cirrhosis for the previous 3 years. From the physical examination, it was found that the general condition was weak, awareness was composed of blood pressure $100 / 60$ pulse 95 $\mathrm{x} /$ minute breathing $24 \mathrm{x} /$ minute temperature $36.5^{\circ} \mathrm{C}$.

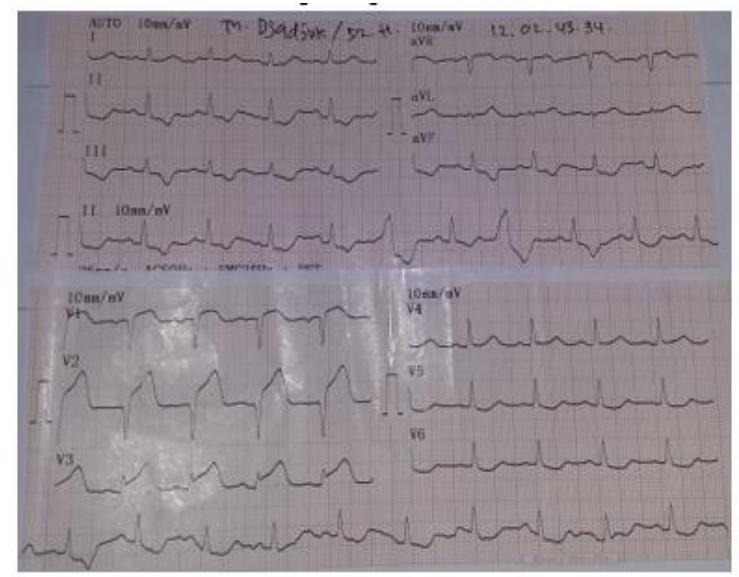

Fig. 1. Electrocardiographic examination.

Electrocardiographic examination at IRD showed a 95 $\mathrm{x} /$ minute sinus rhythm, normal frontal and horizontal axis, acute anteroseptal myocardial infarction with ventricular extracystole episodes, bigemini.

Normal head and neck physical examination, no increase in JVP, thorax examination obtained a single S1 S2 heart auscultation, no murmurs, gallops, and extrasistoles were obtained. Pulmonary auscultation sounded vesicular breath in all lung fields, neither rhonchi nor wheezing from examination of abdomen and extremities within normal limits.

From history, physical examination, and electrocardiography, the diagnosis of acute myocardial ST-anteroseptal infarction was established. Initial therapy was given, namely oxygen with nasal 3 liters per minute, infusion and administration of $300 \mathrm{mg}$ aspirin, $600 \mathrm{mg}$ clopidogrel, and $5 \mathrm{mg}$ sublingual ISDN. Furthermore, the patient was prepared for primary PCI.

Laboratory tests showed $9.5 \mathrm{~g} / \mathrm{dL} \quad \mathrm{Hb}, \quad 8.560$ leukocytes/uL, 79,000/uL platelets, $9 \mathrm{mg}$ BUN/dL, serum creatinine $0.77 \mathrm{mg} / \mathrm{dL}$, glucose $192 \mathrm{mg} / \mathrm{dL}$, albumin $2.74 \mathrm{~g} / \mathrm{dL}$, SGOT $62 \mathrm{U} / \mathrm{L}$, SGPT $27 \mathrm{U} / \mathrm{L}$, potassium $3.7 \mathrm{mmol} / \mathrm{L}$, sodium $141 \mathrm{mmol} / \mathrm{L}$, chloride $111 \mathrm{mmol} / \mathrm{L}$, APTT 20.7 seconds with control 26.0 seconds, PPT 15.4 seconds with control 12 seconds. Increased cardiac enzymes, namely CKMB $171 \mathrm{U} / \mathrm{L}$, and Troponin-I $0.096 \mathrm{ng} / \mathrm{mL}$.

Examination of the chest x-ray shows less inspiring results, with a large heart impression normal, and pulmonary congestion.

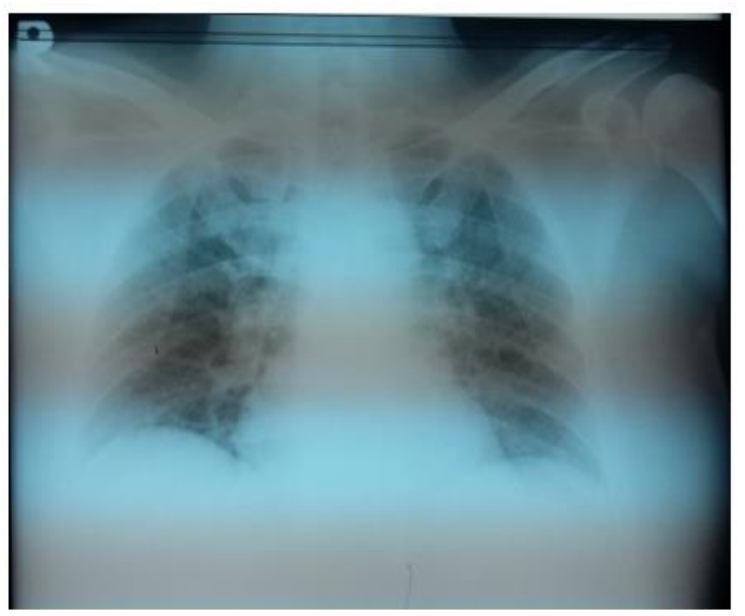

Fig. 2. Examination of chest X-rays.

Furthermore, primary PCI actions with angiographic results, namely Left main coronary artery, are performed. The left anterior descending artery appears diffuse disease from the proximal-distal LAD with a maximum stenosis of $95 \%$ at the proximal LAD. The non-dominant Left circumflex artery shows a significant $70 \%$ stenosis in the distal part. The right coronary artery is dominant, there is a significant $80 \%$ stenosis in the osteal, a significant $80 \%$ stenosis in the mid section.

After angiography is complete, proceed with thrombus aspiration, but no thrombus is obtained. Then stenting DES Firebird II (Rapamycin) $3.0 \times 18 \mathrm{~mm}$ at the proximal LAD directly stenting. PCI is done with good results.

During the PPCI action, it was found that hypotension improved after Dopamine pump was given 5 $\mathrm{ug} / \mathrm{kg} /$ minute, and the patient complained of nausea and then was given Ondancetron 1 ampoule iv. After the action there were no complaints felt by the patient, physical examination showed the presence of fine wet rhonchi on the basal of both lung fields which were then given a 2 ampoule furosemide bolus followed by a pump of $5 \mathrm{mg} /$ hour. The next therapy is Aspirin $1 \times 100$ mg, Clopidogrel 1 x $75 \mathrm{mg}$, Simvastatin 1 x $20 \mathrm{mg}$, ISDN 3 x $5 \mathrm{mg}$, Captopril 3 x $12.5 \mathrm{mg}$, Spironolactone 1 x 25 mg, Ranitidine 2 x 1 ampoule iv, KSR 3 x 1 tab, Lactulose 2 x 15 cc syrup, 3 x 15 cc Sucralfat syrup. 

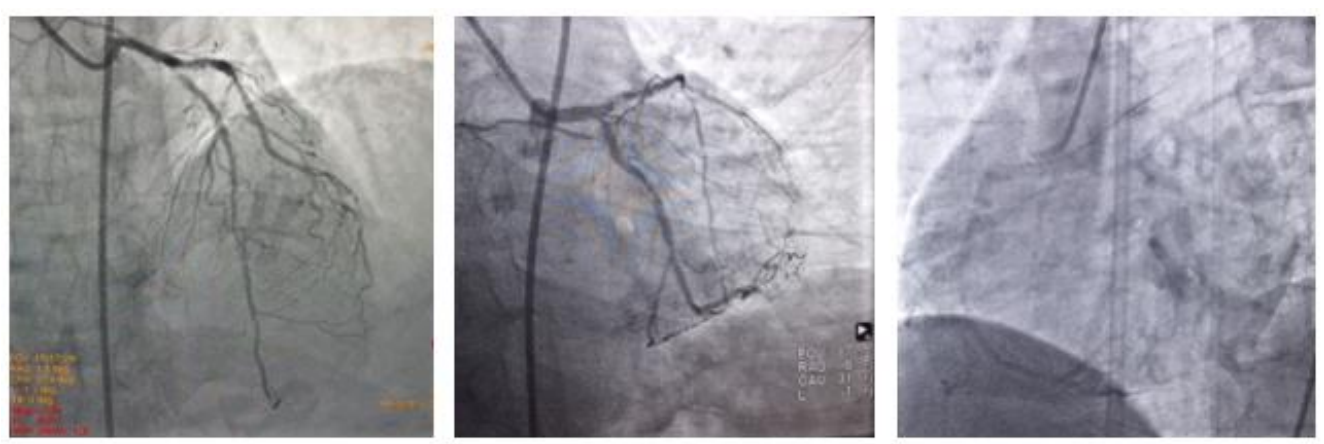

Fig.3. Coronary angiography.

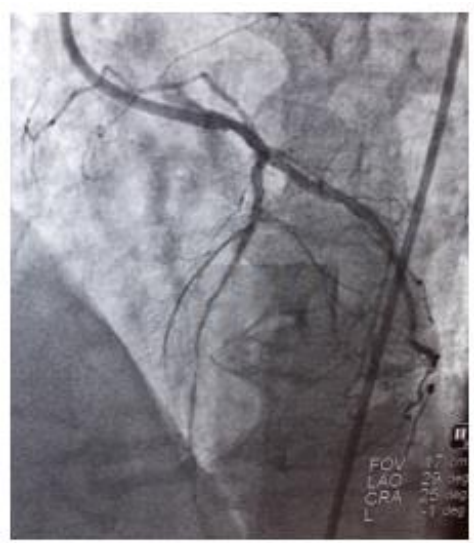

Fig. 4. After installation of stents.

The patient is consulted with the internal medicine department. Patients complain of sometimes nausea. From the examination it was found that patients with anemia ( $\mathrm{Hb} 9.5 \mathrm{~g} / \mathrm{dL})$, thrombocytopenia $(71,600 \mathrm{~g} / \mathrm{dL})$, hypoalbuminemia (albumin $2.74 \mathrm{~g} / \mathrm{dL}$ ). The patient has performed a previous endoscopic examination with grade I-II esophageal varices results, and abdominal ultrasound examination with the results of splenomegaly, parenchymal liver disease, cholelithiasis, and ascites. Conclusion of diagnoses from internal medicine, namely cirrhosis of the liver, esophageal varices of grade I-II, and controlled diabetes mellitus. Therapy given is Diet H1 $1900 \mathrm{kcal} / \mathrm{day}$, injection of Omeprazole 2 x $40 \mathrm{mg}$, Lactulose syrup 2 x $15 \mathrm{cc}$, Sucralfat syrup $3 \times 15 \mathrm{cc}$, and monitor for signs of bleeding.

During hospital treatment, patients have no complaints of chest pain, tightness, or palpitations. The patient also did not experience bleeding. Physical examination found a blood pressure of $120 / 70$, pulse $84 \mathrm{x} /$ minute, breathing $18 \mathrm{x} /$ minute. Thoracic examination or wheezing were not obtained. Electrocardiography shows a sine rhythm of $85 \mathrm{x} /$ minute, normal axis, and pathological Q waves are obtained in V1-V3 stumbling block.

The patient was discharged without complaint with Aspirin 1 x $100 \mathrm{mg}$, Clopidogrel $1 \times 75$ mg, ISDN 3 x 5 mg, Simvastatin 1 x $20 \mathrm{mg}$, Captopril 3 x $12.5 \mathrm{mg}$, Bisoprolol 1 x $2.5 \mathrm{mg}$, Furosemide 1 x $20 \mathrm{mg}$, Spironolactone 1 x $25 \mathrm{mg}$, Lansoprazole 1 x $30 \mathrm{mg}$.

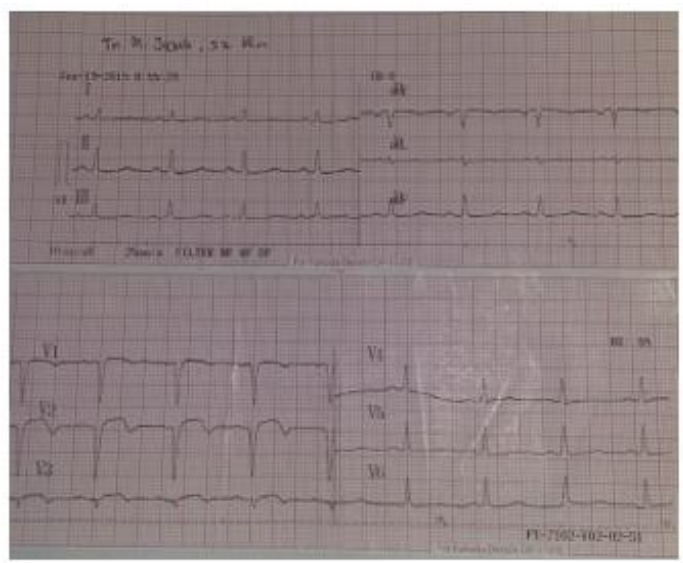

Fig. 5. Electrocardiographic examination during treatment.

\section{DISCUSSION}

Acute STEMI myocardial infarction is a clinical syndrome defined by the symptoms of myocardial ischemia associated with persistent features of electrocardiography (ECG) namely ST segment elevation and an increase in biomarkers as a result of myocardial necrosis (O'Gara et al 2013). Patients have typical chest pain, with risk factors for diabetes mellitus. An ECG examination shows ST segment elevation in the V1-V3 stain which shows an anteroseptal STEMI. 
There are two therapeutic concepts for patients with STEMI, namely PCI and thrombolytics. Primary PCI has become the main choice in the act of reperfusion in STEMI. Compared with thrombolytic therapy in randomized clinical trials, PPCI produced higher patency rates in arteries related to infarction, Thrombolysis in Myocardial Infarction (TIMI) flow grade 3, and lower rates of recurrent ischemia, recurrent infarction, recurrent emergency revascularization procedures, intracranial bleeding, and death (Keeley et al 2003). In these patients, primary PCI therapy is used.

Patients with acute myocardial infarction can be accompanied by other abnormalities that can affect the management of acute coronary syndrome. In this case, the patient is also accompanied by hepatic cirrhosis which results in thrombocytopenia. Treatment of acute coronary syndrome includes antiplatelet, anticoagulant, and PCI where these therapies are associated with the risk of bleeding which is generally delayed in patients with thrombocytopenia. The safety of antiplatelet and PCI therapy in patients with SKA and thrombocytopenia is still unknown, there are no guidelines or randomized studies that suggest a therapeutic approach for these patients (Yusuf et al 2010).

\section{Thrombocytopenia in patients who have primary PCI}

Thrombocytopenia results from abnormal production, platelet distribution, or increased platelet destruction due to hereditary or acquired disease (Overgaard et al 2008). Severe thrombocytopenia $(<50 \times 109 / \mathrm{L})$ is a finding that is rarely found especially in patients with coronary heart disease (Campo et al 2012). Thrombocytopenia is known to be significantly associated with the occurrence of cardiovascular events, major bleeding, and cardiovascular mortality significantly in 30 days in patients with SKA who underwent primary PCI (Judge DA, et al., 2011). In general, the risk of bleeding is still low if the platelet count is still around $50 \times 109 / \mathrm{L}$, but this risk increases sharply if platelets reach 10-20 x 109/L (Tosetto et al 2009). The risk of bleeding in patients with thrombocytopenia varies, depending on the underlying disease. The most common causes of thrombocytopenia are malignancy, liver disease, and immune-related diseases (Spoon et al 2013). For example, thrombocytopenia caused by chemotherapy, spontaneous bleeding is only found in patients with platelet counts below 10 x 109/L (Goldberg et al 1994). In this case the cause of thrombocytopenia is hepatic cirrhosis. There are several factors in liver cirrhosis which result in thrombocytopenia, including splenic sequestration, decreased thrombopoietic activity, bone marrow suppression due to chronic hepatitis $\mathrm{C}$ infection, anti-cancer agents, antiviral therapy with interferon (Hayashi et al 2014).

The cause of coronary thrombosis in patients with thrombocytopenia is still debatable and multifactorial. Even so, from the results of the autopsy the fibrinplatelet thrombus is the same as the thrombus found in the atherosclerosis process. Patients may predispose to the occurrence of coronary thrombosis because of the larger and more adhesive platelet shape to the vascular surface. In patients with acute myocardial infarction or stroke, the average volume of platelets is significantly increased even though the platelet count decreases. Due to natural regulation of platelet production to maintain platelet mass (platelet count and platelet volume on average), it can be concluded that larger platelets not only cause blockage of hemostasis and prevent bleeding due to high activity, but may also be associated with coronary thrombosis in patients with thrombocytopenia (Yusuf et al 2010).

\section{Therapy management}

The safety and tolerability of anticoagulants and antiplatelets have been well described in the general population of SKA, but few data have shown the safety and tolerability of these therapies in patients with thrombocytopenia. Patients with thrombo-cytopenia undergoing PCI have been shown to undergo longer hospitalizations, higher mortality rates when hospitalized, higher rates of bleeding (Overgaard et al 2008). Bleeding is the most common side effect of therapy with anticoagulants and antiplatelets. Therefore, the benefits and risks of giving this therapy must be considered well in order to achieve optimal outcomes and the possibility of minimal bleeding in patients with thrombocytopenia (Yusuf et al 2010).

Aspirin remains an important antiplatelet therapy for patients with SKA. Aspirin therapy in thrombocytopenia is still being debated, there is no widely accepted protocol. One study of people with SKA with cancer-induced thrombocytopenia showed that aspirin was associated with a significant increase in seven-day survival of SKA in patients with SKA with cancer, with or without thrombocytopenia, and not associated with more severe bleeding (Sarkis et al 2007). Aspirin has a short plasma half-life, but has a long biological effect due to irreversible platelet inhibition, as well as P2Y12 antagonists. Because there is no specific reversal agent, the treatment or prevention of bleeding is by stopping antiplatelet therapy. When antiplatelet drugs are stopped, as soon as the function of hemostasis is stable, antiplatelet must be given back immediately. If lifethreatening bleeding is found, platelet transfusion can be considered for the reversal of the antiplatelet effect, but 
the risk of arterial thrombosis is necessary (Makris et al 2012).

The American Heart Association recommends that patients with DES stents be implanted and have a high risk of bleeding so P2Y12 antagonist therapy can be stopped after 6 months of administration (recommendation IIb) (Levine et al 2016). The use of bare metal stents (BMS) is recommended for patients with a high risk of bleeding, who cannot take dual antiplatelet therapy for 12 months. Because the risk of stent thrombosis with BMS is greatest in the first 14 to 30 days, dual antiplatelet therapy is at least 30 days after implantation with BMS (Levine et al 2011).

The study conducted by G. Campo and colleagues showed that there were 35 patients with severe thrombocytopenia who underwent PCI. The use of drugeluting stent (DES) is sometimes still used for certain cases such as stenosis on the left playing artery, overlap on the left anterior descending artery, or small blood vessels. Anticoagulants commonly used are unfractionated heparin (UFH), only 3 people use bivalirudin. There were 20 patients who were recommended for treatment with dual antiplatelet for 6 months, but only 5 patients could meet the target. Nearly half of the study population experienced bleeding complications, the majority of which were superficial bleeding, namely petechiae and ecchymosis. When bleeding occurs, antiplatelet drugs are temporarily delayed. Based on this study, recommendations for medical strategies and interventions, namely first choice arterial access, namely the radial artery, BMS implantation, followed by dual antiplatelet use for 1 month. After that, a minimum of 1 antiplatelet (aspirin $75 \mathrm{mg}$ ) is recommended for life. Periprosedural anticoagulants are operator dependent, and the use of Glycoprotein (GP) IIb-IIIa inhibitors is not recommended. Research conducted by Darcy and colleagues showed that patients with thrombocytopenia $(<100 \times 109 / \mathrm{L})$ who were subsequently performed for coronary angiography had a moderate or large hematoma nine times more often than patients with platelet counts above that value. To minimize this complication, radial arterial access is recommended. In addition, they also stated that being careful in providing therapy, monitoring and follow-up properly can reduce PCI-related bleeding events and can improve compliance with antiplatelet (Darcy et al 1996, Campo et al 2012).

\section{SUMMARY}

Patients with acute myocardial infarction can be accompanied by other abnormalities that can affect the management of acute coronary syndrome. Thrombo- cytopenia is known to be significantly associated with significant cardiovascular events, major bleeding, and cardiovascular mortality in 30 days in patients with SKA who underwent primary PCI. There is still little data that shows the safety and tolerability of anticoagulant and antiplatelet therapy in patients with thrombocytopenia. One recommendation from one institution is for medical strategies and interventions, namely first choice arterial access, namely the radial artery, BMS implantation, followed by dual antiplatelet use for 1 month. After that, a minimum of 1 antiplatelet (aspirin $75 \mathrm{mg}$ ) is recommended for life. Periprosedural anticoagulants are operator dependent, and the use of Glycoprotein (GP) IIb-IIIa inhibitors is not recommended.

\section{REFERENCES}

Campo G, Marchesini J, Fileti L, Tebaldi M, Ferrari R (2012). Medical and interventional management of patients with severe thrombocytopenia undergoing percutaneous coronary intervention. J Thromb Haemost 10, 153-6

Darcy MD, Kanterman RY, Kleinhoffer MA, Vesely TM, et al (1996). Evaluation of coagulation tests as predictors of angiographic bleeding complications. Radiology 198, 741-4

Goldberg GL, Gibbon DG, Smith HO, DeVictoria C, et al (1994). Clinical impact of chemotherapy induced thrombocytopenia in patients with gynecologic cancer. J Clin Oncol 12, 2317-20

Hakim DA, Dangas GD, Caixeta A, Nikolsky E, et al (2011). Impact of baseline thrombocytopenia on the early and late outcomes after ST-elevation myocardial infarction treated with primary angioplasty: Analysis from the Harmonizing Outcomes with Revascularization and Stents in Acute Myocardial Infarction (HORIZONS-AMI) trial. Am Heart J 161, 391-6

Hayashi H, Beppu T, Shirabe K, Maehara Y, Hideo B (2014). Management of thrombocytopenia due to liver cirrhosis: A review. World J Gastroenterol 20, 25952605

Keeley EC, Boura JA, Grines CL (2003). Primary angioplasty versus intravenous thrombolytic therapy for acute myocardial infarction: a quantitative review of 23 randomised trials. Lancet 361, 13-20

Levine GN, Bates ER, Bitti JA, Brindis RG, et al (2016). 2016 ACC/AHA Guideline Focused Update on Duration of Dual Antiplatelet Therapy in Patients With Coronary Artery Disease. JACC

Levine GN, Bates ER, Blankenship JC, Bailey SR (2011). 2011 ACCF/AHA/SCAI Guideline for Percutaneous Coronary Intervention. JACC 58, e44-122

Makris M, Veen JJ, Tait AD, Mumford AD, et al (2012). Guideline on the management of bleeding in 
patients on antithrombotic agents. British Journal of Haematology 160, 35-46

O'Gara PT, Kushner FG, Ascheim DD, Jr DEC, Chung MK. 2013. 2013 ACCF/AHA Guideline for the Management of ST-Elevation Myocardial Infarction: A Report of the American College of Cardiology Foundation/American American Heart Association Task Force on Practice Guidelines. Circulation 127, 362-425

Overgaard CB, Ivanov J, Seidelin PH, Todorov M, et al (2008). Thrombocytopenia at baseline is a predictor of inhospital mortality in patients undergoing percutaneous coronary intervention. Am Heart J 156, 120-4

Sarkiss MG, Yusuf SW, Warneke CL, Botz G, et al (2007). Impact of aspirin therapy in cancer patients with thrombocytopenia and acute coronary syndromes. Cancer 109, 621-7

Spoon DB, Psaltis PJ, Kidd S, Prasar A, et al (2013). Outcomes after PCI in patients with thrombocytopenia. JACC 61, e1718

Tosetto A, Balduini CL, Cattaneo M, DeCandia E, et al (2009). Management of bleeding and of invasive procedures in patients with platelet disorders and/or thrombocytopenia: Guidelines of the Italian Society for Haemostasis and Thrombosis (SISET). Thrombosis research 124, e13-18

Yusuf SW, Iliescu C, Bathina JD, Daher IN, Durand JB (2010). Antiplatelet therapy and percutaneous coronary intervention in patients with acute coronary syndrome and thrombocytopenia. Tex Heart Inst J 37, 336-40. 